Marquette University

e-Publications@Marquette

College of Education Faculty Research and

Publications

Education, College of

8-2014

\title{
Impression Management during Evaluation and Psychological Reactions Post-donation of Living Kidney Donors
}

Lee Hildebrand

Marquette University

Timothy P. Melchert

Marquette University, timothy.melchert@marquette.edu

Rebecca C. Anderson

Medical College of Wisconsin

Follow this and additional works at: https://epublications.marquette.edu/edu_fac

Part of the Education Commons

\section{Recommended Citation}

Hildebrand, Lee; Melchert, Timothy P.; and Anderson, Rebecca C., "Impression Management during Evaluation and Psychological Reactions Post-donation of Living Kidney Donors" (2014). College of Education Faculty Research and Publications. 367.

https://epublications.marquette.edu/edu_fac/367 


\title{
Impression Management During Evaluation and Psychological Reactions Post-Donation of Living Kidney Donors
}

\author{
Lee Hildebrand \\ Department of Counselor Education and Counseling Psychology, \\ Marquette University \\ Milwaukee, WI \\ Timothy P. Melchert \\ Department of Counselor Education and Counseling Psychology, \\ Marquette University \\ Milwaukee, WI \\ Rebecca C. Anderson \\ Division of Transplant Surgery, Medical College of Wisconsin, \\ Milwaukee, WI
}

\begin{abstract}
:
Many health care providers have been concerned about the extent to which potential kidney donors use impression management or concealment of important information regarding their medical history, current functioning, or other circumstances that could affect whether they are accepted as donors. To date, however, there has been very little empirical examination of these

Clinical Transplantation, Vol. 28, No. 8 (August 2014): pg. 855-861. DOI. This article is @ John Wiley and Sons and permission has been granted for this version to appear in e-Publications@Marquette. John Wiley and Sons does not grant permission for this article to be further copied/distributed or hosted elsewhere without the express permission from John Wiley and Sons.
\end{abstract}


NOT THE PUBLISHED VERSION; this is the author's final, peer-reviewed manuscript. The published version may be accessed by following the link in the citation at the bottom of the page.

questions. It is also not known whether donors' use of impression management pre-donation is related to their reactions and adjustment postdonation.

Methods: This study surveyed 76 individuals who had donated a kidney one to six years previously regarding their use of impression management and their concealing of information during their psychological evaluations. They were also asked about their reactions to the donation and whether they would make the same decision again. In addition, 21 of these donors participated in focus groups that explored these questions in depth.

Results: Many of the kidney donors reported that they possessed very strong motivation to donate and consequently used impression management in their interactions with medical professionals pre-donation. Very few donors, however, indicated that they concealed information during their pre-donation evaluations. The donors' psychological reactions post-donation were generally positive and nearly all indicated that they would make the same decision again.

Keywords: kidney transplant, living donor evaluation, impression management, post-donation reactions, psychological factors.

In the six decades since the first kidney transplantation from a living donor, live kidney donation has become a common approach to treating end-stage renal disease (1). Demand for living kidney organ donors has risen steadily since the 1960 s as improvements in transplantation technology have made living kidney donation a viable alternative to hemodialysis and transplantation using organs from deceased donors. Early on, there were concerns that recipient benefits may overshadow the safety and well-being of donors. These concerns subsided, however, as research showed that carefully selected donors could benefit psychologically from donation and public opinion began to embrace the life enhancing potential of living kidney donation (2).

Substantial research has been conducted on the psychological experiences of organ transplant recipients but far less research has examined the psychological experiences of living kidney donors. Donating one's kidney is a generous act, but it can also be a complicated psychological experience. While many donors have strong altruistic motivations, there is concern that some donors approach the decision with ambivalence, passivity, or in response to family pressures $(3,4)$. A better understanding of the informed consent and

Clinical Transplantation, Vol. 28, No. 8 (August 2014): pg. 855-861. DOI. This article is (C John Wiley and Sons and permission has been granted for this version to appear in e-Publications@Marquette. John Wiley and Sons does not grant permission for this article to be further copied/distributed or hosted elsewhere without the express permission from John Wiley and Sons. 
evaluation processes used with potential kidney donors as well as their experiences and reactions following donation could have significant implications for all the stakeholders involved in kidney transplantation.

The purposes of this study were to gain a better understanding of kidney donors' motivations to donate a kidney and assess the extent to which donors report using impression management and concealment of information to influence the clinicians who evaluate them as donor candidates. The definition of impression management used in this refers to "the behavioral strategies that people use to create desired social images or identities" (5). Creating impressions or concealing information regarding one's medical or psychiatric history, finances and employment, social support, tendency to make impulsive decisions, wishes for a special relationship with the recipient following donation, or pressures one is experiencing to donate could directly impact one's acceptance as a donor as well as one's adjustment and reactions post-donation. This study also examined how these factors were related to donors' positive and negative psychological reactions following the donation and whether they would make the same decision again. A literature search found no studies that have investigated these questions. A better understanding of these issues might lead to improvements in the reliability of donor psychosocial evaluations conducted at transplant centers and in donor reactions following transplantation.

\section{Methods}

This study utilized a mixed-methods design. A telephone survey was administered to a larger sample of kidney donors $(n=76)$ to gain more representative data and focus groups were conducted with a smaller sample of donors $(n=21)$ to explore the study questions in more depth.

\section{Procedure}

Living kidney donors served by a transplant center in the Midwestern U.S. during the period of one to six years prior to data collection were contacted by mail with an invitation to participate in the present study. Both related and unrelated donors were invited to participate, though Good Samaritan donors were excluded from participation because they were very few in number and their motives

Clinical Transplantation, Vol. 28, No. 8 (August 2014): pg. 855-861. DOI. This article is @ John Wiley and Sons and permission has been granted for this version to appear in e-Publications@Marquette. John Wiley and Sons does not grant permission for this article to be further copied/distributed or hosted elsewhere without the express permission from John Wiley and Sons. 
for donation tend to differ from those who donate to recipients known to them. The donors were sent a letter explaining the purpose and nature of the study and a copy of the informed consent form. They were also informed that they would be called by phone to ascertain their willingness to participate in the study. If they were not reached on the first call, a second call was made, which was followed by a third call as needed. Voicemails were left whenever possible. No more than three calls were attempted in any case.

During the follow-up phone conversation, a researcher asked for verbal informed consent in order to conduct a brief telephone survey that took approximately 15 minutes to complete (see Table 1 for the questions asked). The 76 donors who agreed to participate in the phone survey were also invited to participate in a 90-minute focus group to discuss the same topics in more detail. The 21 donors who agreed to participate in these groups were divided into smaller groups of 6,7 , and 8 so that each donor's experience could be discussed more fully. An advanced doctoral student in counseling psychology conducted all three focus groups using a script with questions that focused on the same six areas listed in Table 1 (the full script is available from the study authors). The three focus groups were each videotaped and transcribed and a tape-based analysis of the participants' comments was performed by the focus group facilitator to identify the relevant themes expressed in the sessions (6). This analysis was also independently conducted by another advanced graduate student and discrepancies between the two coders were identified and resolved. In addition, a psychologist with over 15 years of experience working with living kidney donors acted as an auditor for this analysis and the accuracy of the themes identified. A research protocol describing all the study procedures was approved by the Marquette University Institutional Review Board and the review board of the hospital where the data were collected.

\section{Results}

\section{Donor Characteristics}

All of the 144 living kidney donors served by the transplant center during the period of one to six years prior to data collection and who were not Good Samaritan donors were contacted to participate in the study. Of that group, 76 agreed to participate in the brief phone

Clinical Transplantation, Vol. 28, No. 8 (August 2014): pg. 855-861. DOI. This article is ( John Wiley and Sons and permission has been granted for this version to appear in e-Publications@Marquette. John Wiley and Sons does not grant permission for this article to be further copied/distributed or hosted elsewhere without the express permission from John Wiley and Sons. 
interview, resulting in a $52.8 \%$ response rate. The mean age of these donors was 49.08 years $(S D=10.47$, range $=26-71)$ and $69.7 \%$ were women. The ethnicity of the donors was self-identified as $92.2 \%$ Caucasian, 3.9\% African-American, and 3.9\% Latino. Of the 76 donors, $32.9 \%$ had donated 1 to 2 years prior to data collection, $21.1 \% 2$ to 3 years prior, $11.8 \% 3$ to 4 years prior, $15.8 \% 4$ to 5 years prior, and $18.4 \% 5$ to 6 years prior to data collection. Fifty-four percent of the donors were first degree relatives of the recipients and $46.1 \%$ were biologically unrelated.

The focus group participants included 21 living kidney donors who, during the phone survey, agreed to participate in the focus group portion of the study. To obtain smaller groups, these 21 donors were divided among three groups consisting of 6,7 , and 8 members. The mean age of these donors was 50.47 years $(S D=10.47$, range $=26$ 71 ) and $67.2 \%$ were women. Their ethnicity was self-identified as 85.7\% Caucasian, 9.5\% Latino, and 4.8\% African-American. Thirtyeight percent were first degree relatives of the recipients and $61.9 \%$ were biologically unrelated donors.

\section{Survey Results}

The large majority of the donors (78.9\%) indicated that their primary motivation to donate was a "desire to help" while a much smaller number indicated "a sense of responsibility or moral duty" $(17.1 \%)$ and 2 donors indicated "religious convictions" as their primary reason to donate (see Table 1). Many of the donors reported that they "tried to create a good impression during [their] evaluation so that [they] would be accepted as a donor," but only one donor indicated that she concealed information that she thought could reduce her chances of being selected as a donor. The reported reactions to the donation tended to be quite favorable, though not in all cases.

The three statistically significant correlations between the survey items were all in the expected directions. Reporting a positive reaction following donation was correlated strongly with donors indicating that they would make the same decision to donate again, $r=.479, p<.01$, as well as inversely correlated with having a negative reaction post-donation $(r=-.413, p<.001)$. There was also a negative correlation between reporting a negative reaction following donation 
NOT THE PUBLISHED VERSION; this is the author's final, peer-reviewed manuscript. The published version may be accessed by following the link in the citation at the bottom of the page.

and donors indicating that they would make the same decision again, $r=-.256, p<.05$.

\section{Focus Group Results}

Motivations to donate. A desire to help was the predominant motivation to donate expressed by the large majority (90.4\%) of the 21 kidney donors in the focus groups. One individual donated to a recipient who was not biologically related and explained: "This man had PKD... his kidneys swelled to an incredible size. His sister and mother were tested and were not found to be appropriate candidates. When I heard about this situation, I wanted to talk to them and see if they would be open to me being tested." Another donor gave religious reasons for wanting to help: "I know that Jesus died for me and I wanted to make a similar sacrifice in order to help my brother."

The second most prevalent motivation described by the donors was a sense of duty $(n=4)$. For example, one donor explained: "It was not that I was guilted into it or anything. It was just the right thing to do. It was a sense of duty." Two other donors expressed a desire to improve relationships within their extended family. One explained that "For me to donate was an easy decision. It was not an easy decision for my husband. He was very skeptical. I did not feel a lot of love in my family and we were not very close because I came from an alcoholic family. For me it was a wonderful opportunity to give to my brother and the family and it was a great opportunity to bring the family together."

The majority of the donors $(n=18)$ reported that their decision to donate was easy because the choice was obvious. The majority $(n=19)$ also emphasized very strong motivations to donate. For example, one donor explained: "When I found out that I was a match, it was a tremendous experience. I have never experienced anything like it in terms of the joy and excitement. I really wanted to do it."

A minority $(n=6)$ of the donors reported that their family members had reservations about donating. These involved concerns about the medical risks involved, pain from the surgery, and the possibility that another family member may need the donor's kidney in the future. These concerns were reported more frequently by those who donated to biologically unrelated recipients. After hearing these

Clinical Transplantation, Vol. 28, No. 8 (August 2014): pg. 855-861. DOI. This article is (C John Wiley and Sons and permission has been granted for this version to appear in e-Publications@Marquette. John Wiley and Sons does not grant permission for this article to be further copied/distributed or hosted elsewhere without the express permission from John Wiley and Sons. 
NOT THE PUBLISHED VERSION; this is the author's final, peer-reviewed manuscript. The published version may be accessed by following the link in the citation at the bottom of the page.

concerns, some of the other donors in the focus groups indicated that they had not asked their children about this issue and in retrospect wished they had.

Use of impression management. The large majority of the donors $(n=18)$ reported that they used some impression management to attempt to influence the treatment team to select them as a donor, and only 3 donors reported that they had been completely candid and did not use impression management at all. The efforts to manage impressions were generally described as mild attempts, however, and these fell into three categories. One group of donors reported they attempted to convince the treatment team that a known psychological issue (e.g., a past trauma or depression) should not interfere with their ability to donate. One individual reported: "I realized I was pretty down because of the loss of my father and the medical issues of my mom. I was concerned how they would take it ... if I indicated I was a little bit depressed...I wanted them to know that I was not crazy. I might seem like it sometimes, but I am not."

Another group of donors reported being aware that their physical health issues might be viewed as a contraindication for donation and described efforts to convince the treatment team that these issues should not prevent them from donating. One person explained: "I had to have some extensive tests because I am an older donor...I worked very hard at working with the treatment team to reach the status of being approved as a donor to my husband. I definitely used impression management in this process." A third group of donors described their attempts to manage impressions as related to their strong motivations to donate their kidney. For example, one individual explained: "When you are asking about whether or not I thought about how my answers would be interpreted before I answered questions on the evaluation, I definitely did. I thought a lot about the psychology beneath it. I asked myself, "Hmmm, what are they looking for here in this? I had a vested interest in donating to my brother-in-law and I know that I did think about my answers and how I came across to the evaluators."

Concealment of information. Four donors reported concealing information they thought might prevent them from donating. In all these cases, the information that was reported as being withheld involved disapproval by certain family members $(n=2)$ or concerns

Clinical Transplantation, Vol. 28, No. 8 (August 2014): pg. 855-861. DOI. This article is @ John Wiley and Sons and permission has been granted for this version to appear in e-Publications@Marquette. John Wiley and Sons does not grant permission for this article to be further copied/distributed or hosted elsewhere without the express permission from John Wiley and Sons. 
that the recipient might not follow through with the treatment guidelines and the kidney would be wasted $(n=2)$. One donor reported: "I concealed some information from the team that I discussed with my husband. My brother-in-law had a heart transplant and ended up not complying with the treatment regimen and ended up dying due to organ failure. I secretly feared my husband might start smoking again and waste the kidney. But I was not going to tell the treatment team that for fear they may not permit me to donate to him." Another donor reported: "The only thing I did not want them to know was that my mother did not approve of my doing this. They asked me if my family was okay with things. I did not admit or volunteer that my mother was upset about me donating."

None of the donors reported that they concealed information that they believed might limit their ability to donate their kidney. One donor explained: "I think the medical things are more straightforward and easier to lay out on the table. However, some of the psychological things you discuss and handle within your family and don't necessarily share that with the treatment team."

Positive post-donation experiences. All of the donors in the focus groups agreed that donating a kidney was a positive psychological experience. Many donors $(n=15)$ reported that their act was held in very high regard by their family members. This was the case even when the donation resulted in the recipient's loss of the kidney graft.

Another benefit reported by the donors was increased selfesteem. One individual who reported experiencing significant abuse as a child reported that her life was significantly changed as a result of the donation: "I will never forget the second day [after] the surgery as I was lying flat on my back in the hospital and I'm looking at the ceiling and all of a sudden I got this big smile on my face because it was my first personal moment with myself ever and I said to myself, 'my God, you did this without any strings, without any condition. I think I like you.' I started liking myself at that point... I've had a smile on my face ever since." Others reported an enhanced sense of meaning and purpose in life followed their donations. One donor explained: "I think it was a reality check for my spouse and a reality check for me on life, living, and the meaning of life...this process caused me to think about the question, 'what have I done in my life

Clinical Transplantation, Vol. 28, No. 8 (August 2014): pg. 855-861. DOI. This article is (C) John Wiley and Sons and permission has been granted for this version to appear in e-Publications@Marquette. John Wiley and Sons does not grant permission for this article to be further copied/distributed or hosted elsewhere without the express permission from John Wiley and Sons. 
NOT THE PUBLISHED VERSION; this is the author's final, peer-reviewed manuscript. The published version may be accessed by following the link in the citation at the bottom of the page.

when I die that is significant?'... It was one of the best things I have done. It was similar to giving birth to my children."

The most frequent positive emotional reaction reported by the donors was a sense of satisfaction in seeing the recipient resume a healthy and functional life $(n=8)$. Several donors also reported that their relationships with extended family members improved following the donation. One donor reported: "It was wonderful to see how this united my family. It is nothing like it was before... Our kids did not even know one another before the donation... It has changed everything." Another donor added: "It is the same for me in regard to family relationships... Even the younger brother that was upset that I was the one to donate is now really close to me and expresses appreciation for me often."

Negative post-donation experiences. A small number of donors reported negative reactions. Two of the biologically unrelated donors reported that the graft kidney they donated was unsuccessful. One of these reported: "After the first day, we realized that we were losing the kidney. My [recipient's] body rejected the kidney... I was a mess and very distraught. Our entire family went through a very trying time because of this... However, the story has a good ending because [that recipient] received a perfect match one year later and is doing well." A small number of other donors $(n=6)$ reported difficulty during periods of temporary rejection of the graft including one who reported: "I think the rejection piece really bothered me. He was doing very well and then went through a short period of rejection. I knew it was not my fault but I still felt emotionally anxious and semi-responsible... But things are going well now."

Several donors also expressed having negative reactions related to noncompliance by the recipient in caring for the kidney. For example, one donor reported: "Just recently things have not gone that well for my husband even though the transplant was initially successful. The reason why is my husband has continued to smoke... This is a hard issue for me."

The decision in retrospect. When the donors were asked if they would make the same decision again, all participants said they would do the same thing without hesitation, including those who experienced less favorable reactions. For example, one donor

Clinical Transplantation, Vol. 28, No. 8 (August 2014): pg. 855-861. DOI. This article is ( ) John Wiley and Sons and permission has been granted for this version to appear in e-Publications@Marquette. John Wiley and Sons does not grant permission for this article to be further copied/distributed or hosted elsewhere without the express permission from John Wiley and Sons. 
NOT THE PUBLISHED VERSION; this is the author's final, peer-reviewed manuscript. The published version may be accessed by following the link in the citation at the bottom of the page.

reported: "I would still die in a heartbeat for something I believed in. And I believed in this. I look at soldiers doing what they're doing and I feel what I did was unheroic in comparison. It was a no-brainer."

Approximately one-half $(n=10)$ of the donors also commented on the importance of support from fellow donors. One donor reported: "I would like to have had an opportunity to meet in groups like this. I would like to have been able to talk to somebody that had already donated. This would've helped me with my fears."

\section{Discussion}

This study found that many of the living kidney donors in the study sample acknowledged using impression management to attempt to influence the treatment team to select them as donors. The comments made by the focus group participants suggests that these were generally mild attempts to minimize known psychological concerns (e.g., past trauma, depression). A small number of donors also acknowledged concealing information to increase their chances of being selected to donate. One percent $(1.3 \%)$ of the donors in the phone survey and $14.2 \%$ of the donors in the focus groups acknowledged concealing information during the evaluation. The comfort level in the focus group setting may have allowed those participants to reveal more of their thoughts compared with those in the telephone surveys. The focus group participants reported concealing disapproval from family members or concerns that the recipient may not follow through with the treatment guidelines and their kidney might be wasted. No evidence was found suggesting that donors concealed information regarding alcohol or drug problems, significant psychological problems, financial difficulties, health problems, or other issues that could be critical in determining their acceptability as a donor.

The reported use of impression management was not statistically significantly correlated with the donors' reported reactions post-donation, suggesting that living kidney donors who utilize impression management do not tend to have negative post-donation reactions to the experience. In addition, no statistically significant relationship was found between donor concealment of information and any other factors. To the extent that the donors accurately reported their experience, these findings do not raise concerns that the use of

Clinical Transplantation, Vol. 28, No. 8 (August 2014): pg. 855-861. DOI. This article is (C John Wiley and Sons and permission has been granted for this version to appear in e-Publications@Marquette. John Wiley and Sons does not grant permission for this article to be further copied/distributed or hosted elsewhere without the express permission from John Wiley and Sons. 
impression management and information concealment by potential kidney donors frequently results in seriously unreliable pre-donation evaluations and potential difficulties with adjustment post-donation.

This study also found very high rates of positive psychological reactions following the donations with $98.6 \%$ of the phone survey participants indicated positive overall reactions and $100 \%$ of the focus groups participants agreeing that the donation was a positive psychological experience. The most frequent positive reaction reported by the focus group donors was satisfaction in seeing the health of the kidney recipient improve.

Less favorable psychological reactions to donation were also reported in this study, however. In the phone survey, $13.2 \%$ of the donors reported negative reactions while $9.2 \%$ of the focus groups participants reported experiencing depression, sorrow, and intense psychological distress that resulted from the failure of the kidney graft following their donation.

Nearly all the phone survey participants (97.4\%) and all the focus group participants indicated that they would make the same decision again to donate their kidney as they look back retrospectively at their whole experience. Even donors who reported negative reactions reported that they would make the same decision again without hesitation. Other studies have found similarly positive reactions after donation (8-17).

It must be noted that the present results cannot be generalized to the general population of living kidney donors. The primary limitation of the focus group portion of the study was its small sample size, though the phone survey included a larger sample with a higher response rate that helped offset this disadvantage. Nonetheless, this study recruited donors from only one transplant center and nearly half of those donors did not agree to participate. The lack of confidentiality in the focus groups may have also resulted in the self-selection of donors with positive dispositions, which could have affected the study results. In addition, the interpersonal nature of the focus groups may have resulted in participants overstating their views on donation due to a desire to manage impressions in front of other former living kidney donors. This is the first study to investigate the prevalence and nature of impression management by living kidney donors, and so the

Clinical Transplantation, Vol. 28, No. 8 (August 2014): pg. 855-861. DOI. This article is (C John Wiley and Sons and permission has been granted for this version to appear in e-Publications@Marquette. John Wiley and Sons does not grant permission for this article to be further copied/distributed or hosted elsewhere without the express permission from John Wiley and Sons. 
present results also cannot be compared with those from other studies. Therefore, the generalizability of the results from the present study is unknown.

This study appears to be the first to investigate the prevalence and nature of the use of impression management and concealment of information by living kidney donors. The nature of the impression management and the information that was reported to have been concealed tends not to raise concerns that impression management by potential kidney donors can result in seriously unreliable pre-donation evaluations and potential difficulties with adjustment post-donation. Nonetheless, one-half of the donors did report using some form of impression management and a small number acknowledged concealing information from the treatment team. Therefore, transplant centers should be alert to the possibility that these factors may affect the information received during living kidney donor evaluations. Transplant centers can consider using assessments designed to detect misrepresentation or faking good when they suspect high levels of impression management or the concealing of information. Developing strong rapport with potential donors can also help staff evaluate the nuances of a donor's psychological presentation. The study results also suggest improvements that might make the kidney donation process more positive for donors. Approximately one-half of the focus groups participants reported that they would have welcomed opportunities to receive support from past donors both before and after the donation.

The questions addressed in the present study are very important to living kidney donation programs. Therefore, replicating and extending this study with more extensive telephone or in-person surveys and more in-depth focus group methodologies with donors from multiple transplant centers will provide data that may help verify the trends found here. Clarifying in more detail the favorable and less favorable experiences of the donors, both before and after the donation, may also lead to the identification of improvements that can be made in kidney donation programming.

Clinical Transplantation, Vol. 28, No. 8 (August 2014): pg. 855-861. DOI. This article is ( ) John Wiley and Sons and permission has been granted for this version to appear in e-Publications@Marquette. John Wiley and Sons does not grant permission for this article to be further copied/distributed or hosted elsewhere without the express permission from John Wiley and Sons. 
NOT THE PUBLISHED VERSION; this is the author's final, peer-reviewed manuscript. The published version may be accessed by following the link in the citation at the bottom of the page.

\section{References}

1. Ingelfinger JR. Risks and benefits to the living donor. New Engl J Med. 2005; 5: 447-450.

2. Surman O, Fukunishi I, Allen T, \& Hertl M. Live organ donation: social context, clinical encounter, and the psychology of communication. Psychosomatics. 2005; 46: 1-6.

3. Lennerling A, Forsberg A, Meyer K, \& Nyberg G. Motives for becoming a living kidney donor. Nephrol Dial Transplantation. 2004; 19: 16001605.

4. Yi M. Decision making process for living kidney donors. J Nurs Scholarsh. 2003; 35: 61-66.

5. Tetlock $P E, \&$ Manstead ASR. Impression management versus intrapsychic explanations in social psychology: A useful dichotomy? Psych Review, 1985; 92: 59-77.

6. Krueger RA, \& Casey MA. Focus groups: a practical guide for applied research ( $4^{\text {th }}$ ed.). Thousand Oaks, CA: SAGE Publications, Inc, 2009.

7. Anderson $\mathrm{MH}$, Bruserud $\mathrm{F}$, Mathisen L, Wahl AK, Hanestad BR, \& Fosse, E. Follow-up interviews of 12 living kidney donors one year after open donor nephrectomy. Clin Transplantation. 2007; 21: 702-709.

8. Brown JB, KarleyML, Boudville N, Bullas R, Garg A, \& Muirhead N. The experience of living kidney donors. Health Soc Work. 2008; 33: 93100.

9. LaPointe Rudow D, \& Brown RS Jr. Role of the independent donor advocacy team in ethical decision-making. Prog Transpl. 2005; 15: 298-302.

10. Simmons RG, Klein SD, \& Simmons RL. Gift of life: The social and psychological impact of organ transplantation. Ontario, CA: Wiley, 1977.

11. Williams AM, Colefax L, O'Driscoll CT, \& Dawson S. An exploration of experiences of living renal donors following donation. Nephrol Nurs $]$. 2009; 36: 423-427.

12. Fehrman-Ekholm I, Brink B, Ericsson C, Elinder CG, Duner F, Lundgren G. Kidney donors don't regret: follow-up of 370 donors in Stockholm since 1964. Clin Transplantation. 2000; 69: 2067-2071.

13. Garcia MFFM, Andrade LGM, Carvalho MFC. Living kidney donors-a prospective study of quality of life before and after kidney donation. Clin Transplantation. 2013; 27: 9-14.

Clinical Transplantation, Vol. 28, No. 8 (August 2014): pg. 855-861. DOI. This article is @ John Wiley and Sons and permission has been granted for this version to appear in e-Publications@Marquette. John Wiley and Sons does not grant permission for this article to be further copied/distributed or hosted elsewhere without the express permission from John Wiley and Sons. 
NOT THE PUBLISHED VERSION; this is the author's final, peer-reviewed manuscript. The published version may be accessed by following the link in the citation at the bottom of the page.

14. Isotani S, Fujisa M, Ichikawa $Y$, Ishimura $T$, Matsumoto $O$, Hamami

G,...Kamidono S. Quality of life of living kidney donors: the short-form 36-item health questionnaire survey. Urology. 2002; 60: 588-592.

15. Johnson EM, Anderson JK, Jacobs C, Suh G, Humar A, Suhr, BD.,...Matas AJ. Long-term follow-up of living kidney donors: quality of life after donation. Clin Transplantation. 1999; 67: 717-721.

16. Shrestha A, Shrestha A, Vallance C, McKane WS, Shrestha BM, \& Raftery AT. Quality of life of living kidney donors: a single-center experience. Transplantation Proc. 2008; 40: 1375-1377.

17. Wiedebusch S, Reiermann C, Steinke FA, Muthny, FA, Pavenstaedt HJ, Schoene-Seifert B,...Buyx AM. Quality of life, coping, and mental health status after living kidney donation. Transplantation Proc. 2009; 41: 1483-1488.

\section{About the Authors}

Timothy P. Melchert : 168F Schroeder Complex, Marquette University, Milwaukee WI 53201, USA;

Tel.: 414-288-7379;

e-mail: tim.melchert@marquette.edu

Clinical Transplantation, Vol. 28, No. 8 (August 2014): pg. 855-861. DOI. This article is ๔ John Wiley and Sons and permission has been granted for this version to appear in e-Publications@Marquette. John Wiley and Sons does not grant permission for this article to be further copied/distributed or hosted elsewhere without the express permission from John Wiley and Sons. 
NOT THE PUBLISHED VERSION; this is the author's final, peer-reviewed manuscript. The published version may be accessed by following the link in the citation at the bottom of the page.

Table 1. Responses to survey items

1. Research suggests people have a variety of motivations to donate a kidney. In your case, what was your primary motivation to donate a kidney?
A desire to help
$60(78.9 \%)$
A sense of responsibility or moral duty
$13(17.1 \%)$
Religious convictions
$2(2.6 \%)$
To meet the expectations of family members
$0(0.0 \%)$
Other:
$1(1.3 \%)$

2. Research suggests that some donors try to create a good impression during the evaluation interviews so that they will be accepted as a donor. Would you say that you tried to create a good impression during your evaluation so that you would be accepted as a donor?
Definitely not
$16(21.1 \%)$
Probably not
$14(18.4 \%)$
I'm not sure
$8(10.5 \%)$
Yes, probably
$22(28.9 \%)$
Yes, I definitely did
$16(21.1 \%)$

3. Research also suggests that some donors may conceal information that they assume may reduce their chances of being accepted as a donor (including, but not limited to, alcohol or drug problems, psychological problems, financial difficulties, or health problems)? Do you feel that you concealed any information during your evaluation interviews?

$\begin{array}{lr}\text { Definitely not } & 72(94.7 \%) \\ \text { Probably not } & 3(3.9 \%) \\ \text { I'm not sure } & 0(0.0 \%) \\ \text { Yes, probably } & 0(0.0 \%) \\ \text { Yes, I definitely did } & 1(1.3 \%)\end{array}$

4. What have been your psychological or emotional reactions after donating your kidney? Overall, would you say it was a positive experience?

$\begin{array}{lr}\text { Definitely not } & 0(0.0 \%) \\ \text { Probably not } & 1(1.3 \%) \\ \text { I'm not sure } & 0(0.0 \%) \\ \text { Yes, probably } & 9(11.8 \%) \\ \text { Yes, I definitely did } & 66(86.8 \%)\end{array}$

Clinical Transplantation, Vol. 28, No. 8 (August 2014): pg. 855-861. DOI. This article is (C John Wiley and Sons and permission has been granted for this version to appear in e-Publications@Marquette. John Wiley and Sons does not grant permission for this article to be further copied/distributed or hosted elsewhere without the express permission from John Wiley and Sons. 
NOT THE PUBLISHED VERSION; this is the author's final, peer-reviewed manuscript. The published version may be accessed by following the link in the citation at the bottom of the page.

5. Did you have any negative psychological/emotional experiences?
Definitely not
$51(67.1 \%)$
Probably not
$13(17.1 \%)$
I'm not sure
$2(2.6 \%)$
Yes, probably
$6(7.9 \%)$
Yes, I definitely did
$4(5.3 \%)$

6. In retrospect, would you still have made the same decision to donate your kidney?
Definitely not
Probably not
I'm not sure
Yes, probably
Yes, I definitely would

$0(0.0 \%)$

$2(2.6 \%)$

$0(0.0 \%)$

$0(0.0 \%)$

$74(97.4 \%)$

Clinical Transplantation, Vol. 28, No. 8 (August 2014): pg. 855-861. DOI. This article is @ John Wiley and Sons and permission has been granted for this version to appear in e-Publications@Marquette. John Wiley and Sons does not grant permission for this article to be further copied/distributed or hosted elsewhere without the express permission from John Wiley and Sons. 